\title{
Effects of wind speed and particulate matter source on surface microlayer characteristics and enrichment of organic matter in southern Chesapeake Bay
}

\author{
Kewen Liu \\ Virginia Institute of Marine Science \\ Rebecca M. Dickhut \\ Virginia Institute of Marine Science
}

Follow this and additional works at: https://scholarworks.wm.edu/vimsarticles

Part of the Marine Biology Commons

\section{Recommended Citation}

Liu, Kewen and Dickhut, Rebecca M., "Effects of wind speed and particulate matter source on surface microlayer characteristics and enrichment of organic matter in southern Chesapeake Bay" (1998). VIMS Articles. 288.

https://scholarworks.wm.edu/vimsarticles/288 


\title{
Effects of wind speed and particulate matter source on surface microlayer characteristics and enrichment of organic matter in southern Chesapeake Bay
}

\author{
Kewen Liu ${ }^{1}$ and Rebecca M. Dickhut \\ Department of Physical Sciences, School of Marine Science, College of William and Mary, Virginia Institute of Marine \\ Science, Gloucester Point
}

\begin{abstract}
Surface microlayer (SM) samples were collected with a rotating cylinder sampler from the York and Elizabeth River estuaries of lower Chesapeake Bay bimonthly from May 1994 through June 1995. Two intensive samplings were also conducted in the York River during different seasons: one in December 1994 and another during June 1995. Four SM samples were collected during each intensive sampling within 4 days. All the samples were analyzed for total suspended particulates (TSP), particulate nitrogen (PN), particulate organic carbon (POC) and dissolved organic carbon (DOC). The thickness of the SM was observed to decrease linearly with increased wind speed. TSP and POC in the SM were found to be enriched up to 1000 -fold over the corresponding subsurface water, and to be exponentially related with wind speed at sampling. Enrichment of DOC in the SM relative to subsurface bulk water was also observed at both sampling sites. Larger average POC/PN ratios and consistently smaller particle sizes were observed in the Elizabeth River compared with the York River, suggesting that the former is heavily influenced by atmospheric deposition, as well as urban and terrestrial runoff, whereas in situ production of particles dominates in the latter. No seasonal trends were observed in the SM characteristics with the exception of particle size fractions in the York River, which fluctuate seasonally presumably due to changes in the dominant phytoplankton species. TSP and POC concentrations in the SM can be described by a first-order wind-driven mixing model. Winddriven mixing of SM DOC was less apparent than for TSP and POC.
\end{abstract}

\section{Introduction}

The surface microlayer (SM) is the top 30 to $300 \mu \mathrm{m}$ of a water body and is the region of an aquatic environment that substances depositing from the atmosphere encounter first. Numerous substances accumulate at the sea surface including lipids and hydrophilic or amphiphilic organic chemicals that exhibit a particularly strong interfacial affinity. The accumulation of organic matter, especially of organic compounds with tension-active properties, also causes a lowering of surface tension values [Jarvis et al., 1967] Consequently, organic matter and contaminants are ennched in the SM as compared to corresponding subsurface water [Ewing, 1950; Parker and Barsom, 1970; Larsson et al., 1974; Hunter and Liss, 1977; Pojasek and Zajicek, 1978, Hardy et al., 1990; Garabetian et al., 1993; Kucklick and Bidleman, 1994; Napolitano and Richmond, 1995; Liu and Dickhut, 1997]. Nonetheless, the composition of the SM remains uncertain due to its dynamic nature and variability in source materials.

Processes occurring in the surface microlayer make it far more important than the size or temporal stability of the reservoir might indicate. Potentially important interfacial processes in the SM include conversion of dissolved organic materials to particulate form, conversions of low-molecular-weight materials into higher-

${ }^{1}$ Now at Harbor Branch Oceanographic Institution, Fort Pierce, Florida. Copyright 1998 by the American Geophysical Union.

Paper number 97JD03736.

0148-0227/98/97JD-03736\$09.00 molecular-weight substances, and photochemical transformation [Carlson, 1993]. The SM is also a site of high biological activity, it has been reported to have different microbiota and a considerably greater number of microorganisms than subsurface waters [Hardy, 1982; Parker and Barsom, 1970; Hardy and Apts, 1989; Cullen et al., 1989; Nesterova, 1990; Maki and Hermansson, 1994]. Moreover, studies have demonstrated that exposure of fish eggs or larvae to contaminated SM from Puget Sound, the North Sea, or southern California nearshore areas results in an increase in chromosomal abnormalities in developing embryos, larval abnormalities and mortality [Cross et al., 1987; Hardy et al., 1987] Therefore, from an environmental perspective, the SM 1 s perhaps one of the most important, but poorly characterized regions of the marine environment.

Chesapeake Bay receives industrial and agricultural pollutants from a variety of sources, which include atmospheric deposition [Webber, 1983; Glotfelty et al., 1990; Leister and Baker, 1994; Skudlark et al., 1994; Dickhut and Gustafson, 1995]. The concentration, exposure level and residence times of these pollutants depend on their biogeochemical cycling in the SM, water column and sediments. To better understand the fate and effects of atmospherically deposited contaminants in an aquatic environment, it is critical to quantitatively understand the structure of the SM, as well as the factors controlling the properties of the SM. In this paper we describe the spatial and temporal variability of total suspended particulates (TSP), particulate organic carbon (POC), particulate nitrogen (PN) and dissolved organic carbon (DOC) in the SM of two southern Chesapeake Bay tributaries, and relate these characteristics to prospective sources of organic matter and physical factors that control the stability of the SM. 


\section{Experimental Methods}

\subsection{Study Area}

Two estuaries adjacent to lower Chesapeake Bay were sampled bimonthly during this 1 year investigation: the York and Elizabeth Rivers (Figure 1). The York River site is located at $36^{\circ} 53.2 \mathrm{~N}$, $76^{\circ} 21.3 \mathrm{~W}$ and is considered a semiurban site, located $\approx 5 \mathrm{~km}$ northwest of a coal/oil-fired power plant and oil refinery, and $1 \mathrm{~km}$ east of a major vehicular river crossing. The Elizabeth River site, which is located at $37^{\circ} 14.3 \mathrm{~N}, 76^{\circ} 14.5^{\circ} \mathrm{W}$, is considered an industrialized site representative of contaminated river estuaries. This site is in close proximity $(<5 \mathrm{~km})$ to Lambert's Point coal terminals, Norfolk Naval Station, and Portsmouth Naval Shipyard; in addition, the site is located centrally within the Hampton Roads metropolitan area with a population of about 1.5 million.

\subsection{Sampling}

More than 20 different sampling techniques have been used to sample the SM [Hardy, 1982]. Each collects a somewhat different depth and type of biological or chemical sample, and this has led to difficulty in comparing results of various investigations. Harvey [1966] first designed the rotating drum SM sampler consisting of a smooth, electrically driven rotating cylinder coated with a readily wetted ceramic material. A similar SM sampler, which consists of a glass cylinder, was used by Carlson et al. [1988]. Automation with continuous removal of SM material from the cylinder and the large surface area of drum samplers make collecting large SM volumes possible with rotating drum samplers. This type of SM sampler was used in this study.

Our sampler was modified from Harvey's [1966] design. Briefly, the sampler consisted of an aluminum frame that supported

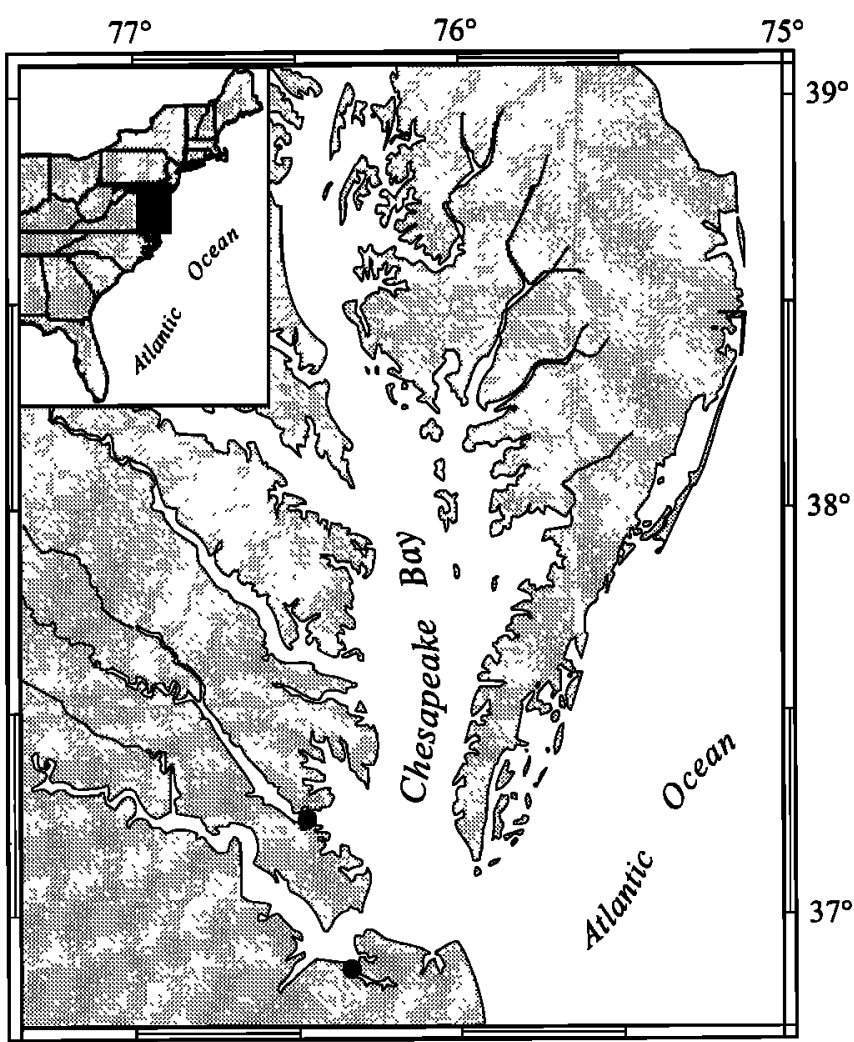

Figure 1. Surface microlayer (SM) sampling sites in the southern Chesapeake Bay region.

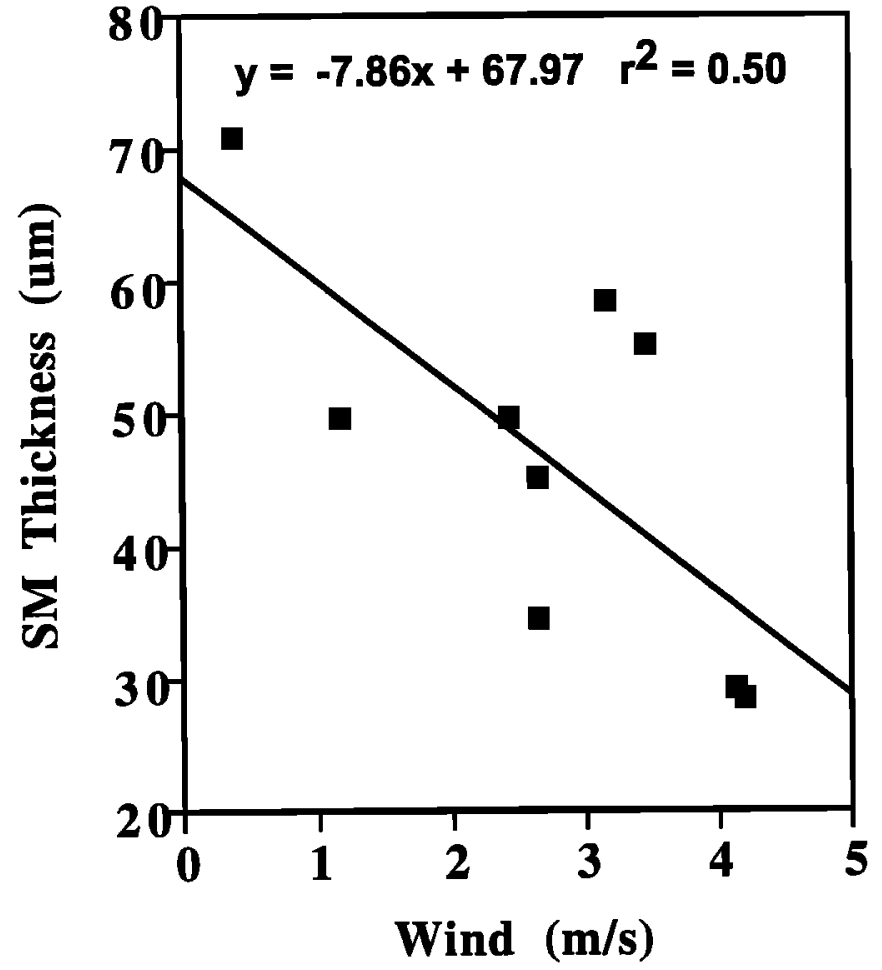

Figure 2. Relationship of SM thickness and wind speed for selected York River samples.

a Teflon-coated stainless steel cylinder. The frame of the sampler was designed so that the submergence depth of the cylinder could be adjusted to achieve optimal sampling efficiency and minimum subsurface water contact. A Teflon blade was mounted on the sampler's surface to remove the SM material as it was picked up by the cylinder. The sampler was deployed from a battery-operated vessel to minimize contamination of the samples with hydrocarbons, data which are presented in another paper [Liu and Dickhut, 1997]. At each site prior to SM sample collection, the cylinder was rotated in the surface water for about $15 \mathrm{~min}$ to remove material that may have adhered to the cylinder during transport.

Integrated SM samples were collected over approximately a 1 mile $(1.6 \mathrm{~km})$ transect. Sampling was conducted on a bimonthly basis at both study sites; however, at the York River site, two intensive samplings were conducted over 4 days to evaluate the short-term variability in SM properties. The SM samples were collected in precleaned $4 \mathrm{~L}$ amber glass bottles using a precleaned stainless steel funnel and stored in a cooler for transport to the lab. Subsequently, the SM samples were homogenized by mixing for about $1 \mathrm{~min}$ and subsampled for TSP, POC, PN and DOC analyses. SM particulate matter was also separated into $<25 \mu \mathrm{m}$ and $\geq 25 \mu \mathrm{m}$ fractions using a $25 \mu \mathrm{m}$ pore size stainless steel screen sieve (Baxter) and gravity sieving the SM media.

\subsection{SM Characteristics}

TSP was determined by filtering homogenized, bulk and sieved $(25 \mu \mathrm{m})$ SM samples through preweighed $47 \mathrm{~mm}$ glass fiber filters (Gelman Type A/E, nominal pore size $1 \mu \mathrm{m}$ ), which were subsequently dried at $60^{\circ} \mathrm{C}$ for 24 hours. Filters were then weighed again to determine TSP, with reported values representing the average of three replicates. DOC was determined on the filtrate using a Shimadzu TOC-500 carbon analyzer, and POC and PN 
were determined using a Carlo Erba NA-1500 elemental analyzer by the Virginia Institute of Marine Science nutrient analytical service laboratory.

\section{Results and Discussion}

\subsection{SM Thickness}

The thickness $(\Delta Y)$ of the SM collected by the rotating drum sampler was determined by the following equation:

$$
\Delta Y=\frac{V}{\pi d l t s}
$$

where $V$ (milliliters) is the SM volume collected over time $t$ (minutes), $d$ and $l$ are the cylinder diameter $(60.9 \mathrm{~cm}$ ) and length $(45.7 \mathrm{~cm})$, respectively, and $s$ is the cylinder's speed of rotation (RPM). Thicknesses for selected York River SM samples ranged from 28.3 to $70.8 \mu \mathrm{m}$. A significant relationship $(p<0.05)$ between wind speed and SM thickness at the York River location (Figure 2) indicates that the operationally defined SM thickness is affected by wind speed. Note that the SM thickness sampled decreases with wind speed, indicating that oversampling (i.e., collection of subsurface water) with increased turbulence is not a problem. Rather, the SM thickness sampled increases approximately two fold with a drop in wind speed from 4 to $1 \mathrm{~m} / \mathrm{s}$. This likely reflects real differences in the thickness of the SM, caused by wind stress and the viscosity of the materials that accumulate at the air-water interface forming the SM. Various models for air-water gas exchange propose that the aqueous boundary layer thickness decreases with increasing wind speed [MacIntyre et al., 1995, and references therein). In the presence of wave-damping surface films, there is also a linear increase in gas exchange coefficients with wind speed [Broecker et al., 1978], presumably due to a corresponding decrease in the hydrodynamic film thickness with increased wind shear, as observed here. Moreover, at low wind speeds the water surface is relatively undisturbed, allowing amphiphilic substances to adhere and accumulate at the arr-water interface. By definition this material is composed of hydrophobic moieties that render the SM more viscous and adhesive to the drum surface. In comparison, at high wind speeds the SM is disturbed and diluted with subsurface water, rendering it less adhesive to the Teflon-coated sampling surface. Therefore, low wind speeds result in thicker surface microlayers and greater enrichments of organic material, as discussed further below.

\subsection{SM Geochemical Characteristics}

TSP for the York River SM ranged from 20.3 to $1500 \mathrm{mg} / \mathrm{L}$, whereas in the Elizabeth River SM, TSP concentrations varied less, ranging from 21.7 to $123 \mathrm{mg} / \mathrm{L}$ (Figure 3 ). The $\mathrm{POC} / \mathrm{PN}$ ratio of the York River SM ranged from 7.6 to 15.7 with an average of 10.1 , and in the Elizabeth River SM, POC/PN ranged from 7.8 to 34.7 with an average of 19.4 (Figure 3). For both sites, no seasonal trends in TSP concentrations or POC/PN in the SM were observed. Moreover, the short-term variability in TSP and POC/PN at the York River site was as large as the seasonal variability.

On average, TSP concentrations in the York River SM were significantly higher $(p<0.1)$ than in the Elizabeth River SM (Figure 3 ), whereas subsurface water TSP levels $(3.2-25.9 \mathrm{mg} / \mathrm{L})$ were not significantly different $(p>0.9)$ between the York and Elizabeth Rivers. Nonetheless, TSP levels in the SM of both rivers were typically enriched relative to subsurface water concentrations. TSP

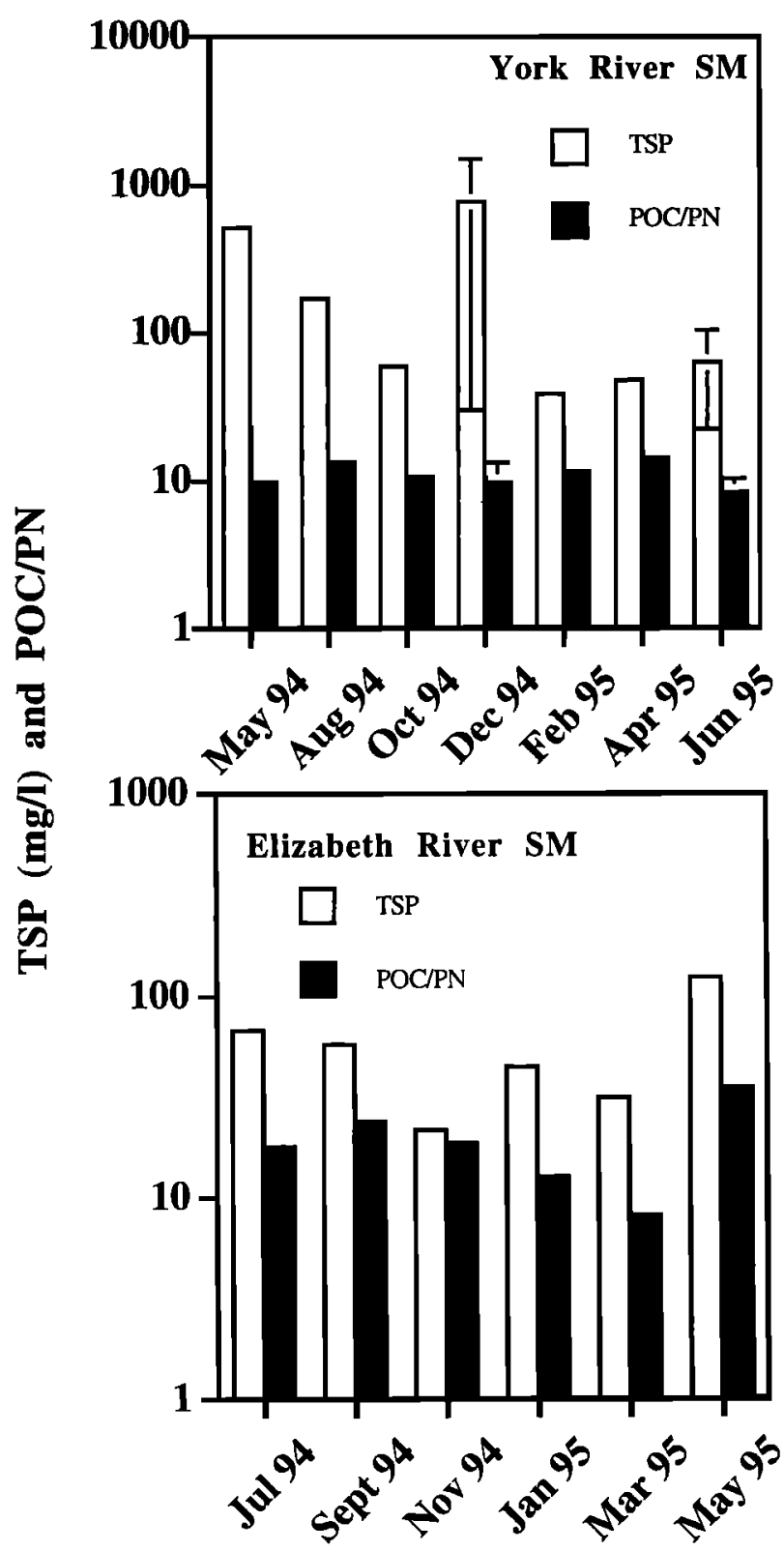

\section{Sampling Date}

Figure 3. TSP and POC/PN in the York (log scale) and Elizabeth (linear scale) River SMs (error bars correspond to sample variability in the two intensive samplings in the York River).

concentrations not only depend on sources of the material, but also on hydrological and meteorological parameters such as wind speed. Lower average wind speeds were recorded during sampling in the York River compared with those in the Elizabeth River, allowing for greater accumulation of particulate matter at the arr-water interface in the York River in contrast to the Elizabeth River. In addition, as stated above, the Elizabeth River is located in an industrial area and is heavily influenced by runoff and discharge from the surrounding watershed. The salt marsh basins in this area have been depleted or substituted by urban development. In contrast, the York River is located in a semirural area and salt marsh basins are more numerous than in the Elizabeth River. 
Therefore, lower TSP in the Elizabeth River SM compared with that of the York River may also be due to decreased abundances of low-density particles such as salt marsh detritus or phytoplankton.

Particulates in the Elizabeth River SM had a significantly higher $(p<0.005)$ POC/PN ratio $(19.4 \pm 9.3)$ than those in the York River SM $(10.1 \pm 2.8)$ (Figure 3 ). The POC/PN ratio provides particle source information; for phytoplankton the ratio is near 6.6 [Redfield et al., 1963], and high POC/PN values indicate particle sources such as terrestrial input [Canuel et al., 1995], woody debris, or petroleum discharge [McGroddy and Farrington, 1995]. The POC/PN ratios measured in this study indicate that particulates in the Elizabeth River SM are enriched in industrial or terrestrial organic matter possibly derived from atmospheric deposition and urban runoff. In comparison, in situ biological production likely contributes a greater fraction of the TSP to SM particles collected in the York River. This is demonstrated by comparing POC, which increased similarly with TSP in both river SMs, to POC/PN, which in the York River SM was relatively constant for all the samples, but in the Elizabeth River SM increased sharply with TSP (Figure 4). These results suggest a relatively constant source of TSP in the

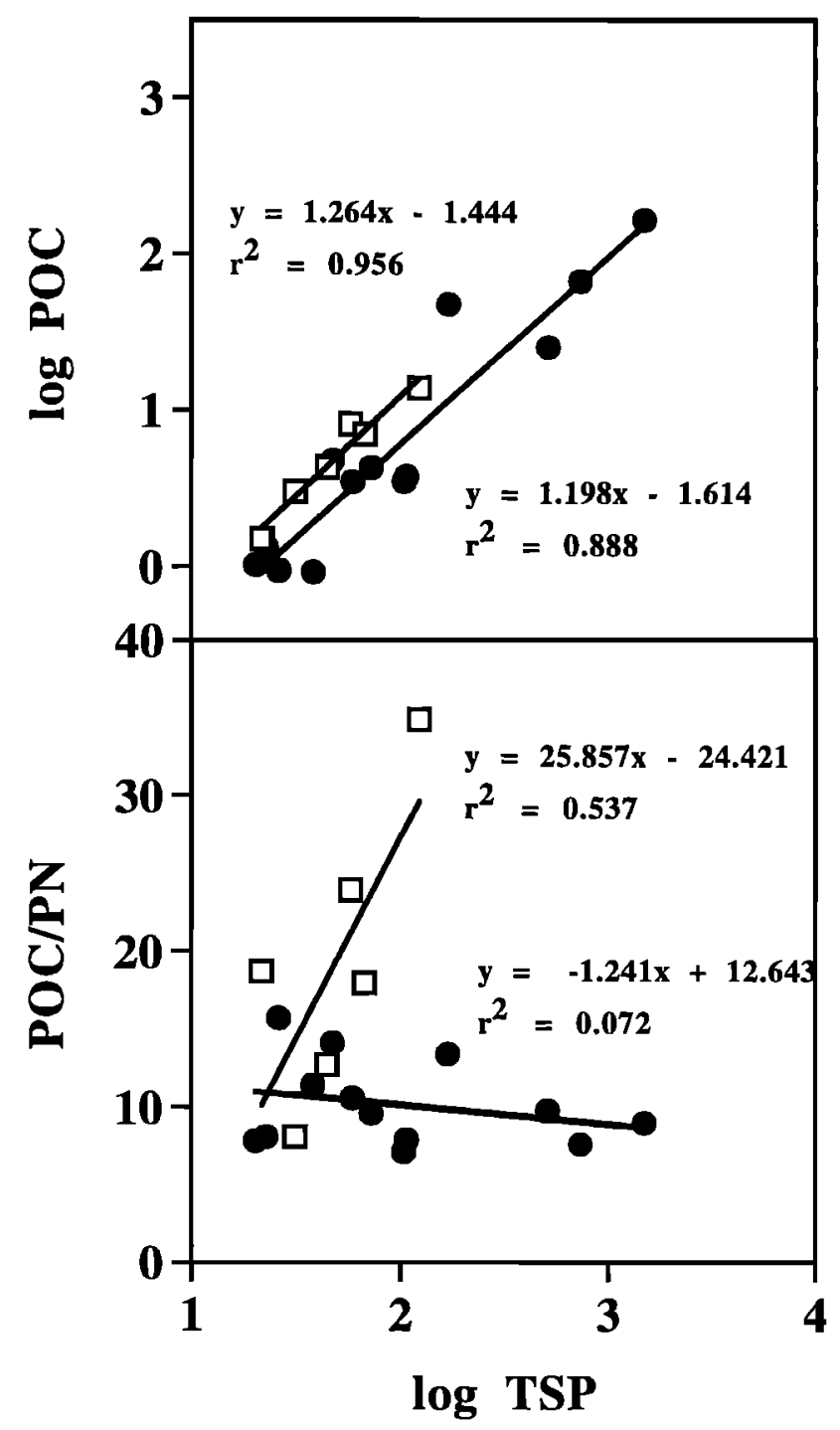

Figure 4. Relationship of (top) POC and (bottom) POC/PN with TSP in the York (solid circles) and Elizabeth (open squares) River SMs.
York River compared with the Elizabeth River and suggest that the TSP source to the Elizabeth River SM was predominantly allochthonous.

Dissolved organic carbon (DOC) exhibited less temporal and spatial variability than TSP and POC concentrations. DOC in the Elizabeth River SM ranged from 4.34 to $9.97 \mathrm{mg} / \mathrm{L}$ and in the York River SM ranged from 4.20 to $20.4 \mathrm{mg} / \mathrm{L}$. Dissolved organic carbon was significantly higher in both the York River SM $(p<0.02)$ and the Elizabeth River SM $(p<0.04)$ than in the subsurface water at each site. This enrichment of dissolved organic material in the SM is probably due to its density and hydrophobicity [MacIntyre, 1974], as well as the surface tension properties of these materials [Jarvis et al., 1967]. Finally, the SM DOC concentrations were found to be significantly $(p<0.05)$ related to POC (and thus TSP) concentrations in the York River, with a similar, but insignificant relationship observed in the Elizabeth River (Figure 5).

\subsection{SM Particle Size Fractionation}

SM particulates were separated into two sizes: $\geq 25 \mu \mathrm{m}$ and 1-25 $\mu \mathrm{m}$. In York River SM samples, the percent mass in each particulate fraction appeared to be seasonal, with small $(1-25 \mu \mathrm{m})$ particles increasing through the winter and spring to an early summer maxima of more than $50 \%$ of the TSP, whereas the larger size fraction of $\geq 25 \mu \mathrm{m}$ particulates made up the biggest component of the SM TSP in the late summer and winter (Figure 6). In the Elizabeth River, however, small particulates accounted for $>50 \%$ of the TSP throughout the year, with little seasonal variability in the percent mass of small and large particles (F1gure 6).

Most large particulates in the water column are from colonial phytoplankton, zooplankton, fecal pellets and detrital aggregates, whereas small particles in the water column are predominantly from nanoplankton, detritus, atmospheric deposition, urban runoff, and resuspended solids [Ward et al., 1994; Ko and Baker, 1995].

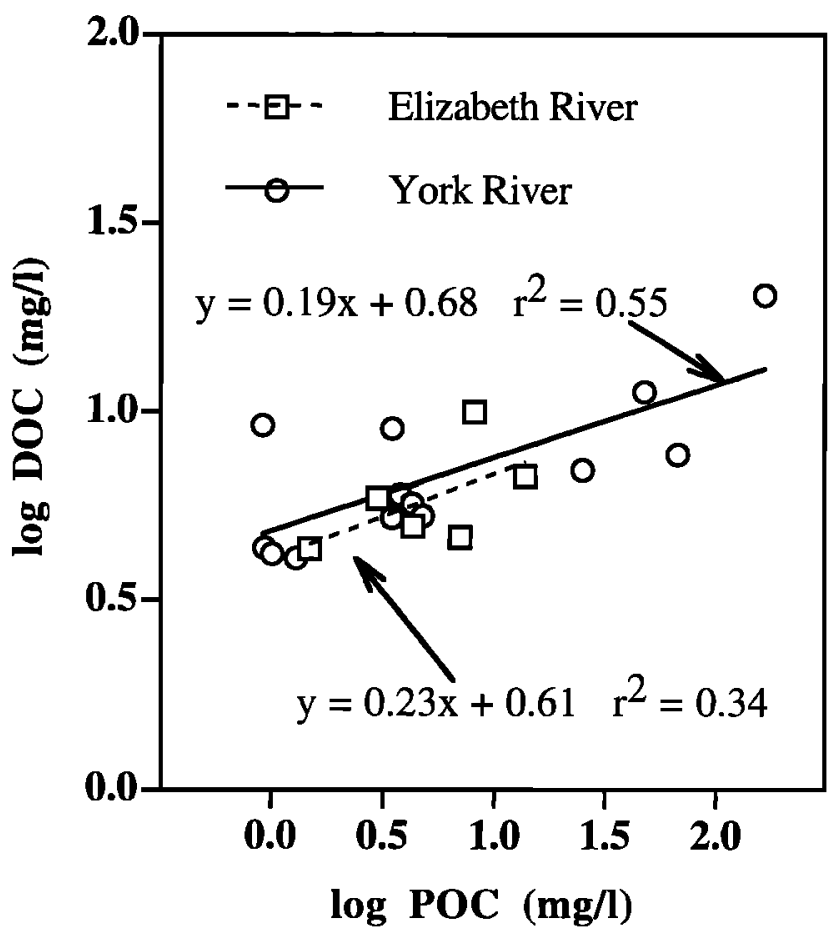

Figure 5. Relationship between DOC and POC in the York and Elizabeth River SMs 


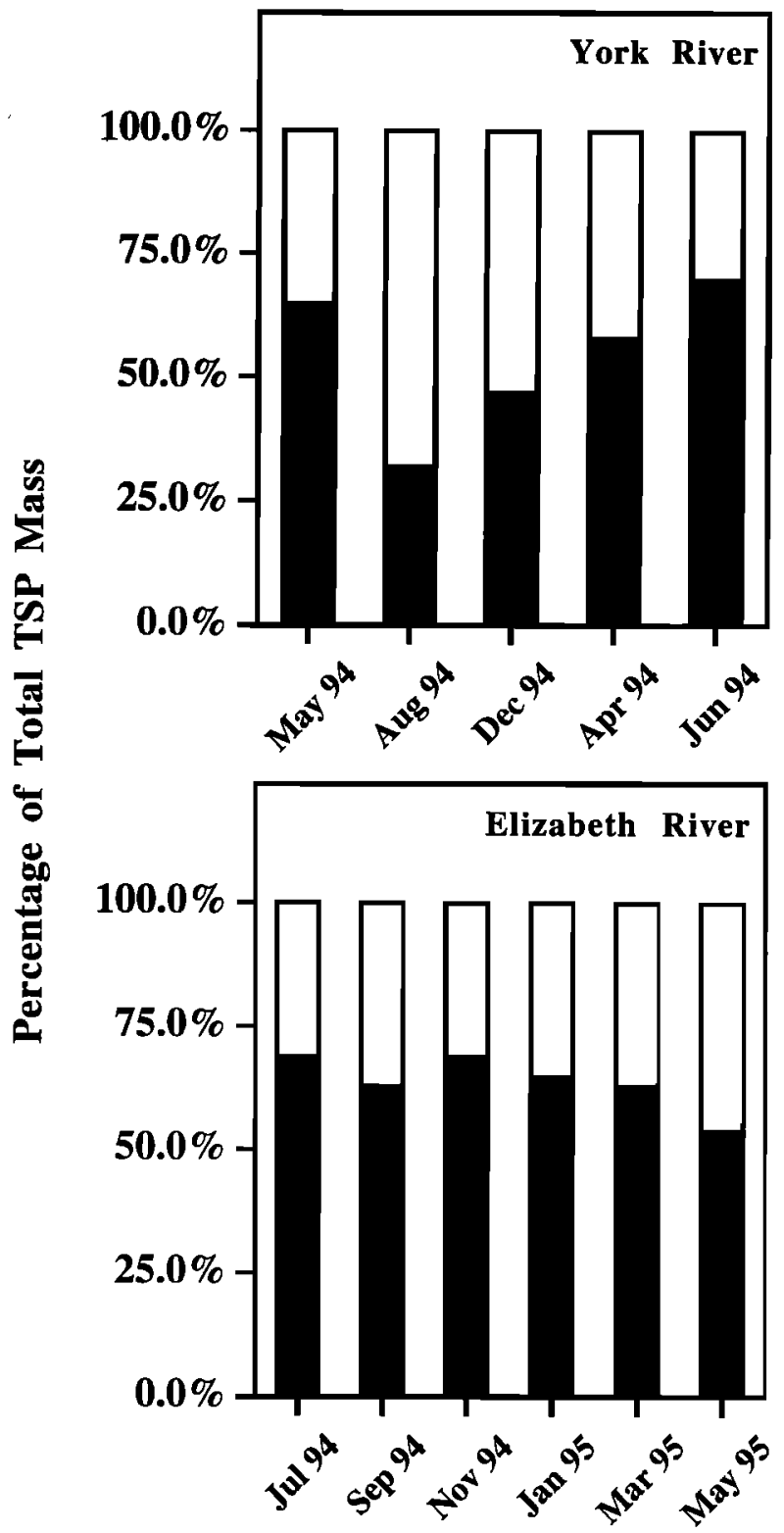

Sampling Date

Figure 6. Particle size contribution to TSP in the York and Elizabeth River SMs: $1-25 \mu \mathrm{m}$ (solid areas of bars); $>25 \mu \mathrm{m}$ (open areas of bars).

Again, comparing SM particulate sizes from the two river systems suggests that higher primary production in the York River, where large diatoms dominate in late summer [Ray et al., 1989] contributes to the greater mass percent of large size particulates observed in this system compared with the Elizabeth River.

\subsection{Wind Speed Effects on SM Characteristics}

With the exception of particle size fractions, no seasonal trends were observed in the SM characteristics. Nonetheless, TSP concentrations in the SM were found to be exponentially related with wind speed (Figure 7, top). In contrast, TSP in the subsurface water, which was sampled at the same time as the SM, was independent of wind speed (Figure 7, top). The two relations converge as wind speed approaches $4 \mathrm{~m} / \mathrm{s}$, which is regarded as the upper-limit wind speed for SM existence [UNESCO, 1985]. Considering that the suspended particulates in the SM are typically hydrophobic or amphiphilic, with densities lower than water, winddriven mixing would be the principal mechanism that distributes suspended particulates collected at the air-water interface into the water column. This process can be described as first-order mixing with TSP fluctuation in the SM resulting from wind force (shear stress) such that

$$
\frac{d\left(T S P_{S M}-T S P_{S W}\right)}{d u}=-k_{m x}\left(T S P_{S M}-T S P_{S W}\right)
$$

where $k_{\max }$ is the wind-driven mixing coefficient $(\mathrm{s} / \mathrm{m}), T S P_{S M}$ and $T S P_{S W}$ represent total suspended particulate concentrations in the SM and subsurface water, respectively, and $u$ is the wind speed $(\mathrm{m} / \mathrm{s})$, which was measured at $10 \mathrm{~m}$ above water level for the Elizabeth River and $40 \mathrm{~m}$ above sea level in the York River.

Applying the integrated form of (2) to the TSP data for the York and Elizabeth Rivers yields significant linear relationships

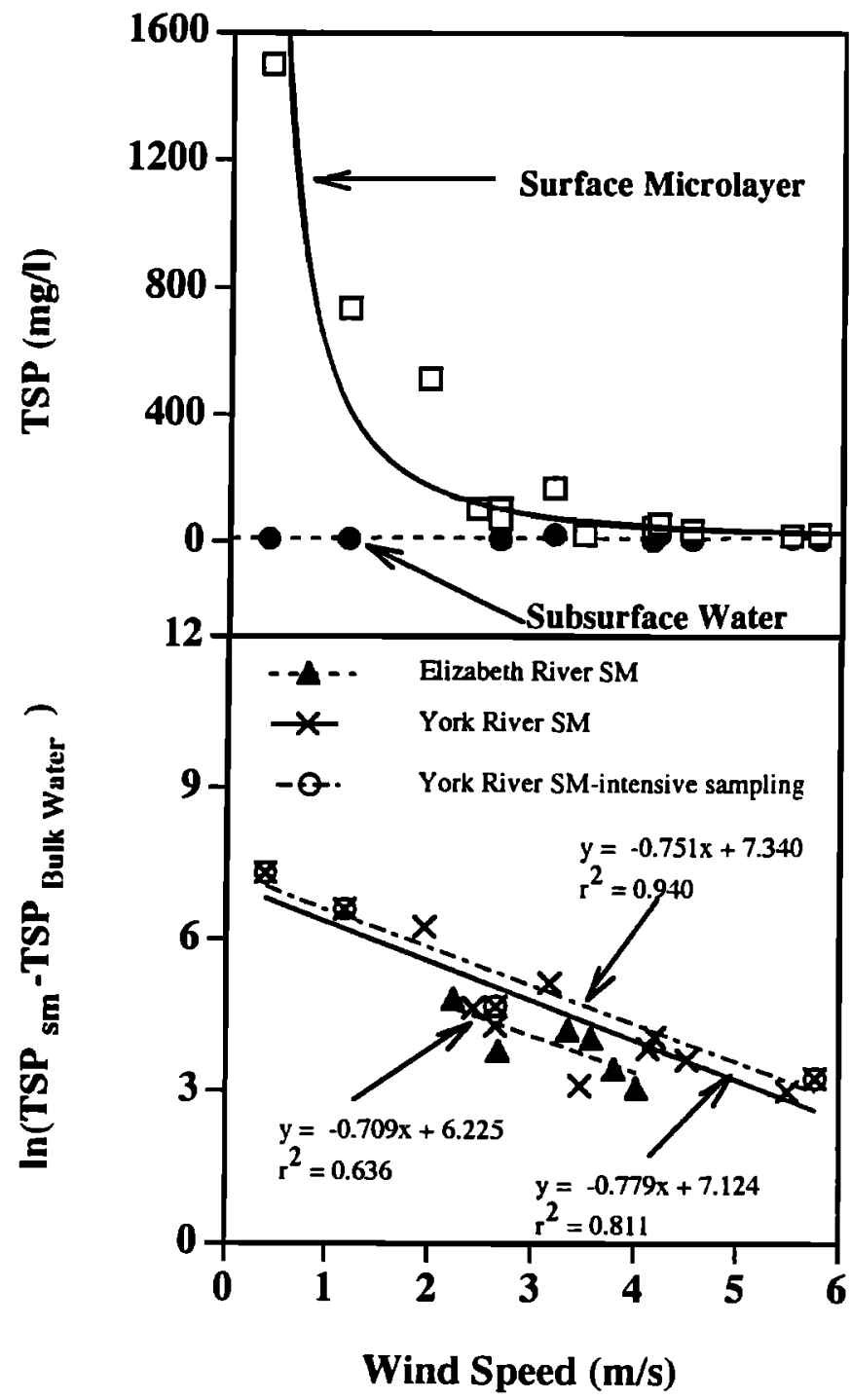

Figure 7. (top) Relationship between TSP and wind speed in the York River, (bottom) fits to the first order mixing model of TSP in the York and Elizabeth River SMs. 
$(p<0.05)$ between the natural log of the TSP gradient between the SM and subsurface water, and wind speed (Figure 7, bottom). The slope in this relation depends on the wind shear at the air-water interface, and the intercept depends on the quantity of particulate material available for mixing. Similar results were observed for the intensive sampling from December 1994 in the York River compared with the data collected throughout the year (regression slopes not significantly different at $p>0.5$ ), which supports the idea that the wind mixing coefficient and the SM TSP concentration of this site are controlled by physical rather than biogeochemical factors. Moreover, using the same model for TSP and wind data from the Elizabeth River site gave similar results as those observed for the York River, with no significant difference between slopes $(p>0.5)$, even though the wind speeds and SM TSP range were much narrower than those in the York River SM. Similar slopes for plots of the integrated form of (2) for both sites indicate that the wind-driven mixing of the SM was comparable at both locations. In contrast, differences in the intercepts for the York River relation and that of the Elizabeth River reflect the greater TSP enrichment relative to subsurface water in the York River SM compared to that of the Elizabeth River (Figure 7, bottom).

TSP enrichment in the SM is affected by both wind speed and the source of particulate matter to the water column, as noted above. For example, greater enrichment of TSP in the York River SM is due to both lower average wind speeds (Figure 7) and greater production of large, buoyant particles (Figure 6) at this site compared to the Elizabeth River. Likewise, enrichment of POC and DOC in the SM relative to subsurface water would be expected in correspondence with the relationships between POC and TSP (Figure 4), and DOC and POC (Figure 5). Using the same type of model used for TSP, we found that accumulation of POC and DOC in the SM of both the York and Elizabeth Rivers was related to wind speed (Figure 8). The regression slopes for POC accumulation in both SMs, and DOC in York River, were significant $(p<0.05)$; however, no significant relation was found for DOC and wind speed in the Elizabeth River $(p>0.5)$. The dependence of POC on wind speed was expected since it is strongly correlated with TSP (Figure 4), which exponentially decreases with increasing wind speed (Figure 7). In contrast, for DOC enrichment the effect of wind speed is less than for POC, reflecting the weaker correlation between these parameters (Figure 5). DOC is smaller in volume and more polar than POC; therefore, DOC is more likely to be readily distributed between bulk water and SM by other mechanisms (e.g., by diffusion) in addition to wind-driven mixing. Consequently, wind-driven mixing may not be as important for DOC as for POC.

\section{Conclusions}

The data presented here demonstrate a linear dependence of SM thickness on wind speed, whereas particulate and organic matter levels in the surface microlayer are exponentially related to wind speed. This latter relationship implies that accumulation of particle and organic matter associated materials such as contaminants in the SM will also be a function of wind shear force at the air-water interface. Moreover, the wind speed dependency of these SM properties illustrates the dynamic nature of this reservoir. Thus, it is likely that accumulation of other materials including neuston, and perhaps microbiota, in the SM will also be dependent on wind speed. Consequently, wind shear force must be taken into account when examining surface microlayer enrichments of various biogeochemically important materials.

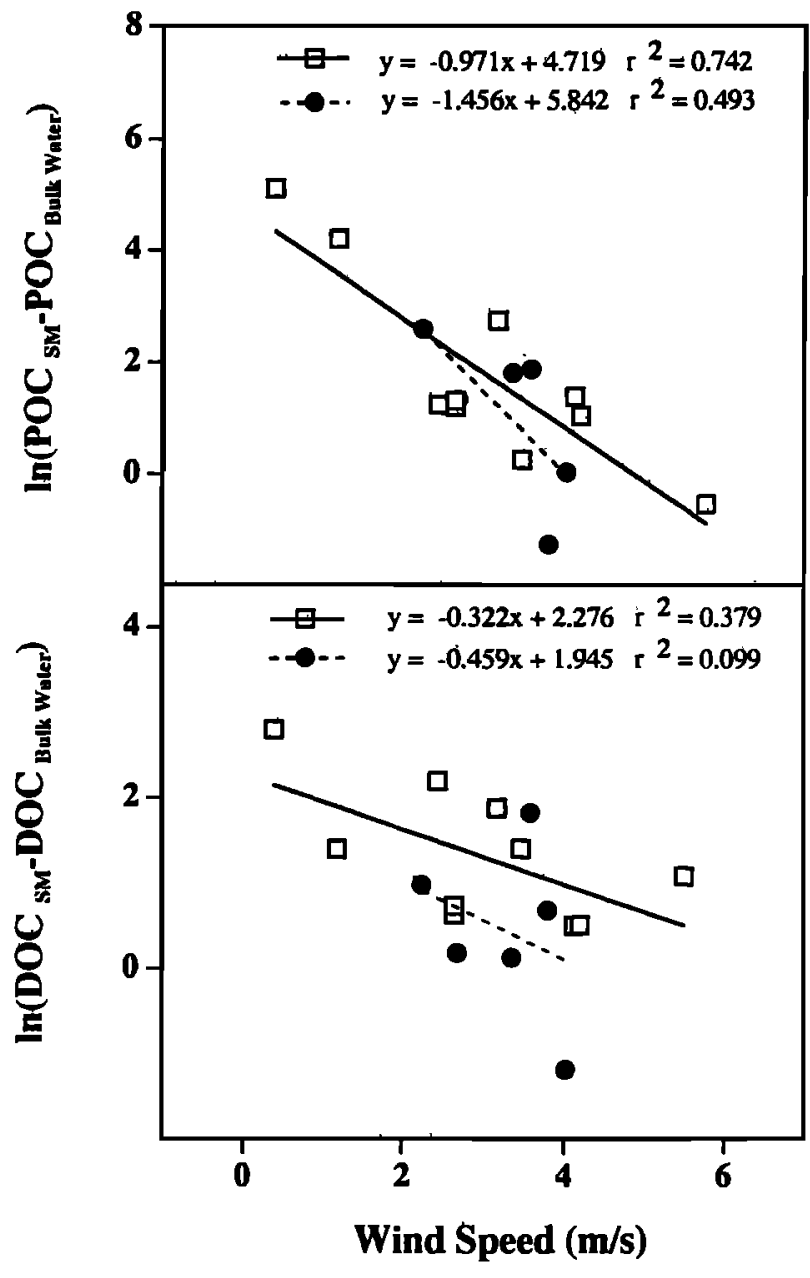

Figure 8. POC and DOC accumulation in the SM fit to the firstorder mixing model (top) relationship between POC and wind speed in the York (open squares) and Elizabeth (solid circles) Rivers; (bottom) relationship between DOC and wind speed in the York (open squares) and Elizabeth (solid circles) Rivers.

Enrichment of suspended particles and organic carbon in the SM is also related to the sources of these materials to aquatic ecosystems. In areas with high in situ production of organic matter such as the York River, TSP enrichment in the SM appears to be related to the buoyancy and density of these particle types. In contrast, small, dense particles presumably derived from runoff and atmospheric deposition, appear to accumulate in the SM of urban estuaries with low productivity such as the Elizabeth River, and are less enriched overall in the surface microlayer. The source of particulate materials to the air-water interface will therefore also play a role in determining enrichments of various particle-derived and associated substances in the surface microlayer.

Acknowledgment. We thank Kurt Gustafson for his help with sample collection and useful discussions, as well as furnishing the subsurface water data for comparison. We also thank Elizabeth MacDonald for technical help. This work is a result of research sponsored in part by the National Sea Grant College Program of the National Oceanic and Atmospheric Administration, U.S. Department of Commerce, under grant NA90AA-D-SG803 to the Virginia Marine Science Consortium and the Virginia Sea Grant College Program. Contribution No. 2113 from the Virginia Institute of Marine Science. 


\section{References}

Broecker, H.-C., J. Petermanin, and W. Siems, The influence of wind on $\mathrm{CO}_{2}$ exchange in a wind-wave tunnel, including the effects of monolayers, $J$. Mar. Res., 36, 595-610, 1978.

Canuel, E.A, J.E. Cloern, D.B. Ringelberg, J.B. Guckert, and G.H. Rau, Molecular and isotopic tracers used to examine sources of organic matter and its incorporation into the food webs of San Francisco Bay, Limnol. Oceanogr., 40, 67-68, 1995.

Carlson, D.J., The early diagenesis of organic matter: Reaction at the air-sea interface, in Organic Geochemistry, edited by M.H. Engel and S.A. Macko, S.A., pp. 255-268, Plenum, New York, 1993.

Carlson, D.J., J.L. Cantey, and J.J. Cullen, Description of and results from a new surface microlayer sampling device, Deep Sea Research, 35, 1205 $1213,1988$.

Cross, J.N., J.T. Hardy, J.E. Hose, G.P. Hershelman, L.D. Antrim, R.W. Gossett, and E.A. Grecelius, Contaminant concentration and toxicity of surface microlayer near Los Angeles, California, Mar. Environ. Res., 23, 307-323, 1987.

Cullen, J.J.; H.L. MacIntyre, and D.J. Carlson, Distributions and photosynthesis of phototrophs in sea-surface films, Mar. Ecol. Prog. Ser., 55, 271-278, 1989.

Dickhut, R.M., and K.E. Gustafson, Atmospheric inputs of selected polycyclic aromatic hydrocarbons and polychlorinated biphenyls to southern Chesapeake Bay, Mar. Pollut. Bullet. 30, 385-396, 1995.

Ewing, G., Slicks, surface films and internal waves. J. Mar. Res., 9, 161-187, 1950.

Garabetian, F., J. Romano, and R. Paul, Organic matter composition and pollutant enrichment of the sea surface microlayer inside and outside slicks, Mar. Environ. Res., 35, 323-339, 1993.

Glotfelty, D.E., G.H. Williams, H.P. Freeman, and M.M. Lech, Regional atmospheirc transport and deposition of pesticides in Maryland. In Long Range Transport of Pesticides, edited by D. Kurtz, pp. 199-222, A.F. Lewis, New York, 1990.

Hardy, J.T., The sea surface microlayer: biology, chemistry and anthropogenic enrichment progress in oceanography, Prog. Oceanogr. 11, 307-328, 1982.

Hardy, J.T., and C.W. Apts, Photosynthetic Carbon Reduction: High Rates in the Sea-Surface Microlayer, Mar. Biol., 101, 411-417, 1989.

Hardy, J.T., E.A. Crecelius, L.D. Antrim, V.L. Broadhurst, C.W. Apts, J.M. Gurtisen, and T.J. Fortman, The sea surface microlayer of Puget Sound, II, Concentrations of contaminants and relation to toxicity, Mar. Environ. Res., 23, 25-71, 1987.

Hardy, J.T., E.A. Crecelius, L.D. Antrim, S.L. Kiesser, and V.L. Broadhurst, Aquatic surface microlayer contamination in Chesapeake Bay, Mar. Chem., $28,333-351,1990$

Harvey, W.G. Microlayer collection from the sea surface: A new method and initial results, Limnol. Oceanogr., 11, 608-613, 1966.

Hunter, K.A, and P.S. Liss, The input of organic materials to the ocean: Airwater interactions and the organic chemical composition of the sea surface microlayer, Mar. Chem., 5, 361-379, 1977.

Jarvis, N.L., W.D. Garrett, M.A. Schelman, and C.O. Timmons, Surface chemical characterization of surface-active materials in sea water, $\mathrm{Ltmnol}$. Oceanogr., 12, 88-96, 1967

Ko, F., and J.E. Baker, Partitioning of hydrophobic organic contaminants to resuspended sediments and plankton in the mesohaline Chesapeake Bay, Mar. Chem., 49, 171-188, 1995.

Kucklick, J.R., and T.F. Bidleman, Organic contaminants in Winyah Bay, South Carolina I: pesticides and polycyclic aromatic hydrocarbons in subsurface and microlayer waters, Mar. Environ. Res., 37, 63-78, 1994.
Larsson, K., G. Odham, and A. Sodergren, On lipid surface films on the sea, simple method for sampling and studies of composition, Mar. Chem., 2, 49 . $57,1974$.

Leister, D.L., and J.E. Baker, Atmospheric deposition of organic contaminants to Chesapeake Bay, Atmos. Envtron., 28, 1499-1520, 1994.

Liu, K., and R.M. Dickhut, Surface microlayer enrichment of polycyclic aromatic hydrocarbons in southern Chesapeake Bay, Environ. $S C$. Technol., 31, 2777-2781, 1997.

Macintyre, F., The top mm of the ocean, Sci. Am., 230(5), 62-67, 1974.

MacIntyre, S., R. Wanninkhof, and J.P. Chanton, Trace gas exchange across the air-water interface in freshwater and coastal marine environments, in Biogenic Trace Gases: Measuring Emissions from Soll and Water, edited by P.A Matson, and R.C. Harriss, R.C., chap. 3, Blackwell Sci., Càmbridge, Mass., 1995.

Maki, J.S., and M. Hermansson, The dynamics of surface microlayer in aquatic environments, in The Brology of Particles in Aquatic Systems, edited by R.S. Wotton, pp. 161-182, A.F. Lewis, New York, 1994.

Mcgroddy, S.E., and J.W. Farrington, Sediment porewater partitioning of polycyclic aromatic hydrocarbons in three cores from Boston Harbor, Massachusetts, Environ. ScI. Technol., 29, 1542-1550, 1995.

Napolitano, G.E., and J.E. Richmond, Enrichment of biogenic lipids, hydrocarbons and PCBs in stream-surface foams, Environ. Toxicol. Chem., 14, 197 201, 1995.

Nesterova, D.A. Study of the Black Sea phytoplankton (in Russian), Mar. Ecol., 34, 1-8, 1990.

Parker, B., and G. Barsom, Biological and chemical significance of surface microlayer in aquatic ecosystems, Blosclence, 20, 87-93, 1970.

Pojasek, R.B., and O.T. Zajicek, Surface microlayers and foams-source and metal transport in aquatic systems, Wat. Res., 12, 7-10, 1978.

Ray, R.T., and L.W. Hass, and M.E. Sieracki, Autotrophic picoplankton dynamics in a Chesapeake Bay sub-estuary, Mar. Ecol. Prog. Ser., 52, 273-285, 1989.

Redfield, A.C., and B.H. Ketchum, and F.A Richards, The influence of organisms on the composition of sea water, in The Sea, vol 2, pp. 26-77, edited by M.N. Hill, Wiley-Interscience, New York, 1963.

Skudlark, J.R, K.M. Conko, and T.M. Church, Atmospheric wet deposition of trace elements to Chesapeake Bay: CBAD study year 1 results, Atmos. Environ. 28, 1487-1498, 1994.

UNESCO, Procedure for sampling the sea surface microlayer, IOC Manuals and Gulde 15, Paris, 1985.

Ward, G.M, A.K. Ward, C.N. Dahm, and N.G. Aumen, Origin and formation of organic and inorganic particles in aquatic systems, in The Btology of Particles in Aquatic Systems, edited by R.S. Wotton, pp. 45-73, A.F. Lewis, New York, 1994.

Webber, D.B. Aerial flux of particulate hydrocarbons to the Chesapeake Bay Estuary. Mar Pollut. Bull., 14, 416-421, 1983.

R.M. Dickhut, Virginia Institute of Marine Science, Department of Physical Science, School of Marine Science, College of William and Mary, Gloucester Point, VA 23062. (e-mail: rdickhut@vims.edu)

K. Liu, Harbor Branch Oceanographic Institution, 5600 U.S. 1 North, Fort Pierce, FL 34946.

(Received April 29, 1997; revised December 9, 1997; accepted December 22, 1997.) 